\title{
Seeds of Calotropis procera Treated With Essential Oils of Copaifera langsdorffii Desf. and Syzygium aromaticum L.
}

\author{
Ronimeire T. da Silva ${ }^{1}$, Maria de F. Q. Lopes ${ }^{1}$, Miguel A. Barbosa Neto ${ }^{1}$, Otília R. de Fárias ${ }^{1}$, \\ Luciana C. do Nascimento ${ }^{1} \&$ Riselane de L. A. Bruno ${ }^{1}$ \\ ${ }^{1}$ Department Plant Science and Environmental Sciences, Federal University of Paraíba, Areia, Paraíba, Brazil \\ Correspondence: Ronimeire T. da Silva, Department Plant Science and Environmental Sciences, Federal \\ University of Paraíba, Areia, Paraíba, Brazil. E-mail: ronimeiretorres@hotmail.com
}

Received: September 15, 2018

Accepted: October 25, 2018 Online Published: December 15, 2018

doi:10.5539/jas.v11n1p438

URL: https://doi.org/10.5539/jas.v11n1p438

\begin{abstract}
The Silk Flower (Calotropis procera) is widely used by farmers in the Northeast region, due to the adaptation of the climatic and soil conditions of the semi-arid region, but the incidence of pathogens has reduced the physiological and sanitary quality standards acceptable for sexual propagation of these plants in the field. Thus, the objective of this research was to verify the effects of the Copaíba (C. langsdorffii) and Cravo (S. aromaticum) oils on the health and physiological quality of silk flower seeds (C. procera) harvested in the city of Tacima, PB. The treatments were constituted by Copaíba (C. langsdorffii) and Cravo ( $S$. aromaticum) essential oils at concentrations of $0.5 ; 1 ; 1.5 ; 2 \%$ and the fungicide Captan ${ }^{\circledR}\left(240\right.$ g, i.a. $100 \mathrm{~kg}^{-1}$ seed). The control 0 (zero) corresponded only to the immersion of the seeds in distilled and sterilized water (ADE). In the evaluation of sanity, the method of incubation on filter paper (Blotter test) was performed, using twenty replicates of 10 seeds for each treatment. The physiological quality was evaluated by the germination test $(\mathrm{G} \%)$, first germination count (FGC), germination speed index (GSI) and seedling dry mass (SDM). A microflora composed mainly of Alternaria sp. (52\%), Fusarium sp. (70\%), Helminthosporium sp. (40\%), Cladosporium sp. (50\%), Curvularia sp. (20\%) and Nigrospora sp. (5\%). The essential oils considerably reduced the percentage of fungi associated with silk flower seeds, but there was moderate phytotoxic effect under the germination and vigor of C. procera seeds.
\end{abstract}

Keywords: alternative control, germination, vigor

\section{Introduction}

The Caatinga Biome has great economic potential still unexplored with a diverse native and exotic vegetation. Knowledge about the potentialities of caatinga species is necessary for the preservation of plant genetic resources, and the sustainability of the population that seeks food and income sources in this region (Oliveira et al., 2011). Among these species, the silk flower (Calotropis procera (Aiton) R. Br.), A shrub, belonging to the Apocynaceae family, although native to Asia, has adapted well to the Brazilian tropical environment. Has green fruits that turn yellow at the end of maturation, with numerous brown seeds, trapped by silky and long hairs, forming winged structures that allow their propagation through the air (Mariod et al., 2017).

The Silk Flower has several economical uses, such as forage production due to the there is no leaf fall even during the dry season of drought and crude protein content around 19.4\% (Torres et al., 2010). An important characteristic of $C$. procera is its regrowth vigorous after cutting, giving this larger plant ease of handling and obtaining (Silva et al., 2017). It stands out as a raw material in the manufacture of fabrics, ornamentation, wood extraction for firewood and home made medicinal applications; its seeds are raw material for biodiesel production (Rangel \& Nascimento, 2011, Oliveira-Bento et al., 2013).

Due to these characteristics, the study of the physiological quality of the seeds becomes important, since the seed is the basic input in the production, and vigorous plants originate from good quality seeds (Vechiat \& Parisi, 2013). According to Henning (2005), the most efficient means of disseminating pathogens is by seed, which facilitates the introduction of diseases into new areas and reduces production due to seedling death. Thus, the use of alternative treatments appears as a preventive measure for problems related to the presence of pathogens in seeds, in addition to eliminating the fungal microflora, it is necessary that the treatment does not have negative effect on the physiological quality. 
Alternative treatments have been gaining ground due to their efficiency in eliminating pathogens and reducing costs, in addition to the beneficial action to the environment, they do not leave residues, and avoid the resistance of microorganisms by the continuous use of chemical products (Santos et al., 2008, Lazarotto et al., 2009), and can replace fungicides, herbicides, insecticides and nematicides.

Among the alternative treatments, plant extracts and essential oils have effective fungal action; the results obtained are promising in the control of phytopathogens (Mondego et al., 2014). Santana (2015) working with Nim essential oils (Azadirachta indica A. Juss.); Thyme (Thymus vulgaris L.); Cinnamon (Cinnamomum zeylanicum J. Presl.); Camphor (Cinnamomum camphora L.) and Melalueca (Melalueca alternifolia). They observed a significant effect on both inhibition of mycelial growth (PIC) and Conidiapores.

Boukaew et al. (2017) tested essential oils of Clove (Syzygium aromaticum (L.) Merr. \& LM Perry) and Vatica (Vatica diospyroides) on the antifungal activity of Aspergillus flavus, and found that both contained Eugenou and Benzyl Acetate, antifungal compounds, in their compositions; the essential oil of $V$. diospyroides, showed $100 \%$ inhibition of A. flavus conidia, whereas $S$. aromaticum oil inhibited $84.7 \%$ of the conidia in Zea mays seeds. The use of copaíba essential oil considerably reduced the incidence of fungi associated with bean (Phaseolus lunatus) seeds without reducing the physiological quality of the seeds (Guedes et al., 2016). The antimicrobial activity of an essential oil is linked to its functional groups and their composition, such as alcohols, phenols, terpenes and ketones (Sartorelli et al., 2007).

Because of the importance of $C$. procera and action provided by the use of essential oils with antifungal activity in seed treatment, aimed to verify the effects of Copaíba oil (Copaifera langsdorffii) and Cravo (Syzygium aromaticum) on the health and physiological quality of (Calotropis procera) seeds.

\section{Material and Methods}

The work was developed in the Laboratories of Seed Pathology and Seed Analysis, Federal University of Paraíba (UFPB), Campus II Areia, PB. Seeds of C. procera were obtained from the municipality of Tacima, PB $6^{\circ} 29^{\prime} 8^{\prime \prime}$ South $35^{\circ} 37^{\prime} 51^{\prime \prime}$ West. The seeds were collected randomly, directly from 4 matrices and in open fruits, at an advanced stage of maturation, and were then packaged in paper bags and benefited in the Seed Analysis Laboratory.

The treatments were constituted by Copaíba (Copaifera langsdorffii) and Cravo (Caryophyllus aromaticus L.) essential oils at concentrations of $0.5 ; 1.0 ; 1.5 ; 2.0 \%$ and the fungicide Captan ${ }^{\circledR}\left(240 \mathrm{~g}\right.$, i.a. $\left.100 \mathrm{~kg}^{-1} \mathrm{seed}\right)$. The control 0 (zero) corresponds to the immersion of the seeds in distilled and sterilized water (ADE). The seeds were immersed in the treatments for a period of five minutes, after which the sanity and physiological quality of the seeds were analyzed. This time was based on pre-liminary tests.

The sanitary quality of the seeds was evaluated by the method of incubation on filter paper (Blotter test), using 200 seeds (twenty replicates of 10 seeds) for each treatment. The seeds were distributed in Petri dishes, containing two sheets of filter paper $\left(80 \mathrm{~g} / \mathrm{m}^{2}\right)$ previously sterilized and moistened with sterile distilled water (ADE), incubated at $20 \pm 2{ }^{\circ} \mathrm{C}$ with photoperiod of 12 hours. The quantitative and qualitative evaluations of the fungi associated to the seeds were carried out after seven days of incubation, and the seeds were examined individually under the stereoscopic microscope.

The seed quality was determined by germination test (MAPA, 2009), using 200 seeds (four replicates of 50 seeds) for each treatment, using as substrate germitest ${ }^{\circledR}$-type paper moistened with distilled water in the amount equivalent to three times the weight of dry paper (MAPA, 2009). Later they were placed to germinate in a germination chamber with a constant temperature of $30{ }^{\circ} \mathrm{C}$, with photoperiod of $8 \mathrm{~h}$ light and $16 \mathrm{~h}$ dark (Oliveira-Bento et al., 2013). The evaluations for the first and last germination counts were performed at 5 and 10 days, respectively, after sowing (Oliveira-Bento et al., 2013). The results were expressed as percentage of normal seedlings (MAPA, 2009).

As for the vigor tests, the first germination count (FGC) was performed, which corresponds to the number of normal seedlings computed on the 5th day after the test installation and the germination speed index (GSI), both performed simultaneously with the test of germination, with evaluation of the seedlings daily, at the same time, from the first day after sowing. The evaluations were carried out until the last count (tenth day), using the formula proposed by Maguire (1962).

To evaluate the dry mass of the seedlings, 20 seedlings of each treatment were randomly chosen. The seedlings were conditioned in paper bags and placed in an oven at $65^{\circ} \mathrm{C}$ until reaching a constant mass (48 hours), being weighed in an analytical balance $(0.001 \mathrm{~g})$. The mean dry matter mass of the seedlings was obtained by the 
quotient between the total mass recorded and the number of normal seedlings used, with results expressed in $\mathrm{g}$. seedling $^{-1}$ (Nakagawa, 2012).

The experimental design was the completely randomized in a factorial scheme $(2 \times 5)$, two oils versus five concentrations, with 4 replicates/treatment. The data were submitted to regression analysis using the means obtained in the ANAVA for the different oil concentrations. The SISVAR 4.5 software was used in the analysis of variance and regression (Ferreira, 2014).

\section{Results and Discussion}

The incidence of fungi associated with silk flower seeds (Calotropis procera) was represented by Alternaria spp. (52\%), Fusarium spp. (70\%), Helminthosporium spp. (40\%), Cladosporium spp. (50\%), Curvularia spp. (20\%) and Nigrospora spp. (5\%) (Figure 1).

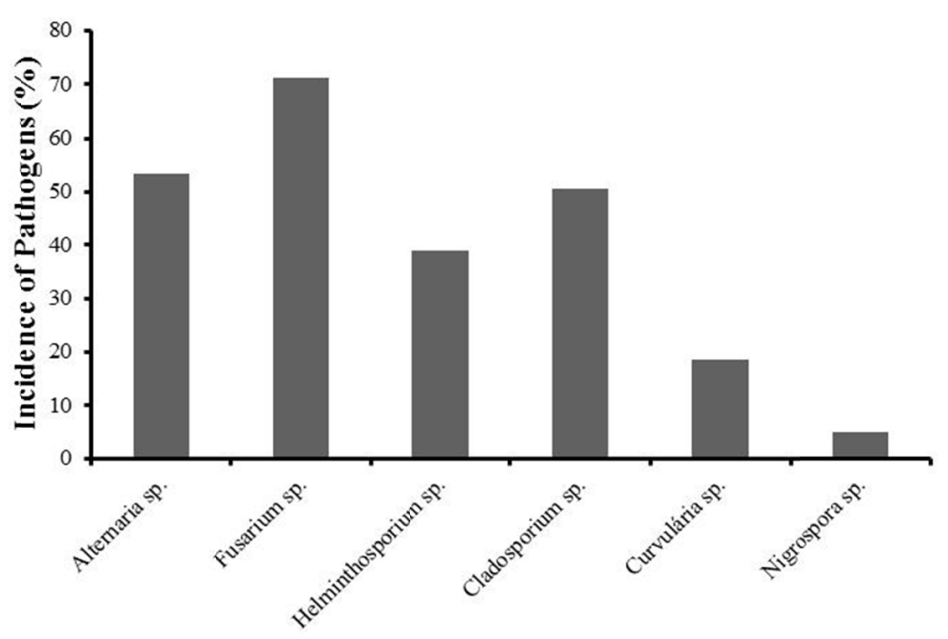

Figure 1. Incidence of fungi on seeds of Calotropis procera from the municipality of Tacima, PB

There was a significant effect for the treatment at a $1 \%$ probability level for all variables studied. Concentrations of the essential oils were also significant at $1 \%$ except for dry mass of the seedlings. The separated tested oils were significant at 5\% probability germination Speed Index (Table 1). 
Table 1. Summary of the analysis of variance for the characteristics percentage germination (G\%), first germination count (FGC), germination speed index (GSI) and Dry mass of seedlings (DMS) in seeds of Calotropis procera submitted to treatment with Copaifera langsdorffii and Syzygium aromaticum oil

\begin{tabular}{|c|c|c|c|c|c|}
\hline \multirow{2}{*}{ SV } & \multirow{2}{*}{$\mathrm{DF}$} & \multicolumn{4}{|c|}{ MS } \\
\hline & & $\% \mathrm{G}$ & FGC & GSI & DMS \\
\hline Treatment & 9 & $453.377 * *$ & $646.711 * *$ & $23.944 * *$ & $0.002 * *$ \\
\hline Concentration & 3 & $301.833 * *$ & $307.458 * *$ & $13.854 * *$ & $0.000^{\mathrm{ns}}$ \\
\hline Linear & 1 & $562.500 * *$ & $342.225^{*}$ & $28.257 * *$ & $0.0008^{*}$ \\
\hline Quadratic & 1 & $40.500^{\mathrm{ns}}$ & $325.125^{*}$ & $1.739^{\mathrm{ns}}$ & $0.00004^{\mathrm{ns}}$ \\
\hline Oils & 1 & $32.000^{\mathrm{ns}}$ & $10.125^{\mathrm{ns}}$ & $7.411 *$ & $0.00007^{\mathrm{ns}}$ \\
\hline $\mathrm{C} \times \mathrm{O}$ & 3 & $49.333^{\mathrm{ns}}$ & $208.125^{*}$ & $5.097 *$ & $0.0001^{\mathrm{ns}}$ \\
\hline $\mathrm{C} / \mathrm{OC}$ & 3 & $84.916^{\mathrm{ns}}$ & $310.916 * *$ & $7.436^{* *}$ & $0.0004^{\mathrm{ns}}$ \\
\hline Linear & 1 & $140.450^{\mathrm{ns}}$ & $174.050^{\mathrm{ns}}$ & $14.145^{* *}$ & $0.001 *$ \\
\hline Quadratic & 1 & $72.250^{\mathrm{ns}}$ & $756.250 * *$ & $8.008^{*}$ & $0.000002^{\mathrm{ns}}$ \\
\hline $\mathrm{D} / \mathrm{OCR}$ & 3 & $266.250 * *$ & $204.666^{*}$ & $11.515^{* *}$ & $0.00006^{\mathrm{ns}}$ \\
\hline Linear & 1 & $470.450 * *$ & $168.200^{\mathrm{ns}}$ & $14.112 * *$ & $0.00009^{\mathrm{ns}}$ \\
\hline Quadratic & 1 & $0.250^{\mathrm{ns}}$ & $4.000^{\mathrm{ns}}$ & $0.931^{\mathrm{ns}}$ & $0.00006^{\mathrm{ns}}$ \\
\hline Fun vs $4 \times 2+1$ & 1 & $1254.400 * *$ & $2310.400 * *$ & $17.459 * *$ & $0.008 * *$ \\
\hline Water vs $4 \times 2+1$ & 1 & $1408.177 * *$ & $1488.400 * *$ & $121.661 * *$ & $0.0089 * *$ \\
\hline Error & 30 & 35.133 & 51.266 & 1.099 & 0.0001 \\
\hline CV \% & & 7.99 & 10.65 & 9.91 & 1.24 \\
\hline Average & & 69.87 & 67.2 & 10.58 & 0.95 \\
\hline
\end{tabular}

Note. ** Significant at 1\%, ${ }^{*}$ Significant at 5\% and ns: not significant. SV: Source of variation; d.f.: Degrees of freedom; MS: Mean squares; CV: Coefficient of variation. Fun (Fungicide); Oils Copaíba (OC); Oils Cravo (OCR).

As the concentration of the Copaíba (Copaifera langsdorffii) and Cravo (Syzygium aromaticum) essential oil was increased, there was a reduction in the percentage of the fungus. Being the concentration of $2.0 \%$ reduced the percentage of Alternaria, not statistically different from the fungicide used (Captan ${ }^{\circledR}$ ), with a $50 \%$ reduced pathogen percentage, to $30 \%$ with the use of oils (Figure 2A).
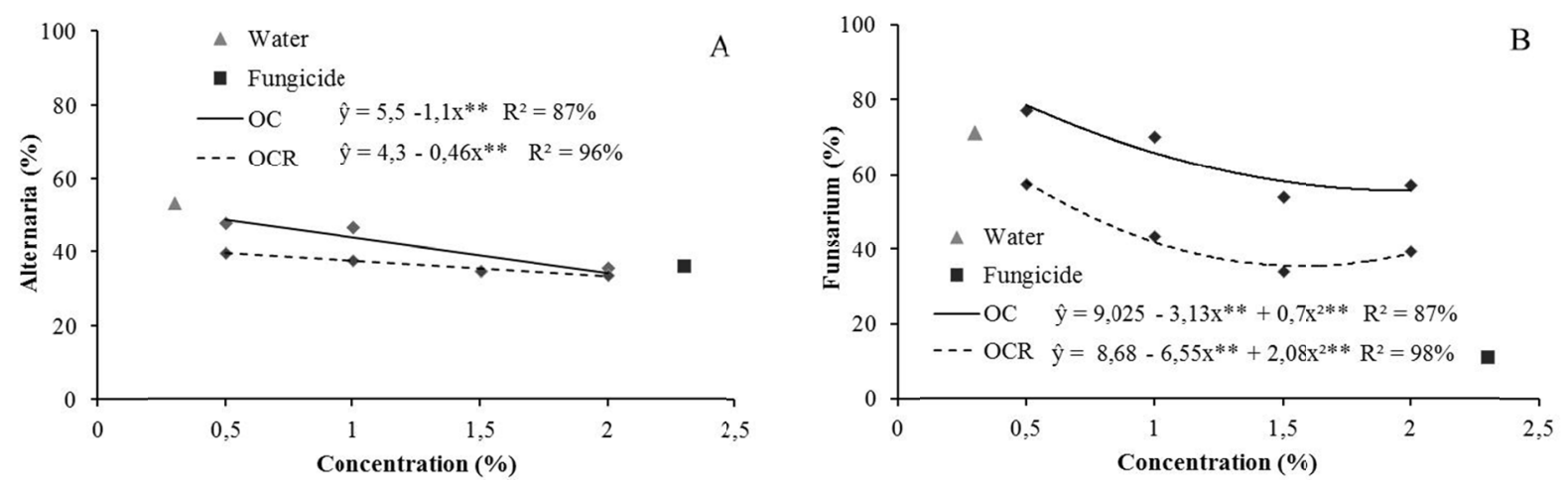

Figure 2. Incidence of Alternaria sp. (A) and Fusarium sp. (B) in seeds of Calotropis procera treated with essential oils of Copaifera langsdorffii and Syzygium aromaticum from the municipality of Tacima, PB

These results differ from Amaral and Bara (2005) in which they observed an antifungal action of clove oil in concentrations of 0.1 to $0.5 \%$ on phytopathogens present in rice, beans, soybean and corn (Oriza sativa, Phaseolus vulgaris, Glycine Max and Zea mays), respectively, reducing the pathogen by one hundred percent. The antifungal effect of copaiba oil is attributed to the substances present in its composition. Zimmermam-Franco et al. (2013) verified that the main substances found in the oil of this plant are $\beta$-caryophyllene, caurenoic acid compounds and $\gamma$-murolene, which are known to have antibacterial and antifungal properties, causing a synergistic effect resulting from the action of their functional groups (Boukaew et al., 2017). 
The incidence of Fusarium spp. in the seeds of C. procera, the existence of the fungus in this area may be due to the fact that the fruits open at the end of maturation, some of which may have been infected (Figure 2B). The infected seeds are important source of primary inoculum for the fungi, causing deterioration, impairing the germination, causing root rot in the seedlings. There is a significant effect on the waste oils, with the percentage of the pathogen increasing from $60 \%$ in the control to less than $40 \%$ when using clove oil at a concentration of 2\%. Similar results were observed by Costa et al. (2011) evaluated the action of the essential oil of Syzygium aromaticum on the hyphae of some phytopathogenic fungi (Rhizoctonia solani, Fusarium solani, Fusarium oxysporum and Macrophomina phaseolina), and concluded that the oil caused cell damage to fungi. This action of the oil can be justified by the presence of Eugenol, an antiseptic phenolic compound of known action (Ranasinghe et al., 2002; Daferera et al., 2003; Amaral \& Bara, 2005; Gayoso et al., 2005).

Antifungal action of the oils on Helminthosporium infestation was observed (Figure 3A), while the concentrations of the oils increased, with a decrease in the percentage of the pathogen, however, clove oil at the concentration of $2 \%$ had a greater effect, reducing from $40 \%$ (distilled water) to $10 \%$, but the fungicide (captan ${ }^{\circledR}$ ) eliminated the pathogens from the seeds. The action of fungicides in the control of seed pathogens is an old practice performed by the producers. Goulart (2001) observed significant reductions in the incidence of pathogens in soybean seeds (Glycine max) when treated with tolylfluanid + thiophanate methyl, thiabendazole + thiram and thiophanate methyl + thiram. Similarly, Pereira et al. (2009) obtained an $82 \%$ reduction in the occurrence of Colletotrichum truncatum in soybean seeds (Glycine max). Similarly, Pereira et al. (2009) obtained an $82 \%$ reduction in the occurrence of Colletotrichum truncatum in soybean seeds (Glycine max).
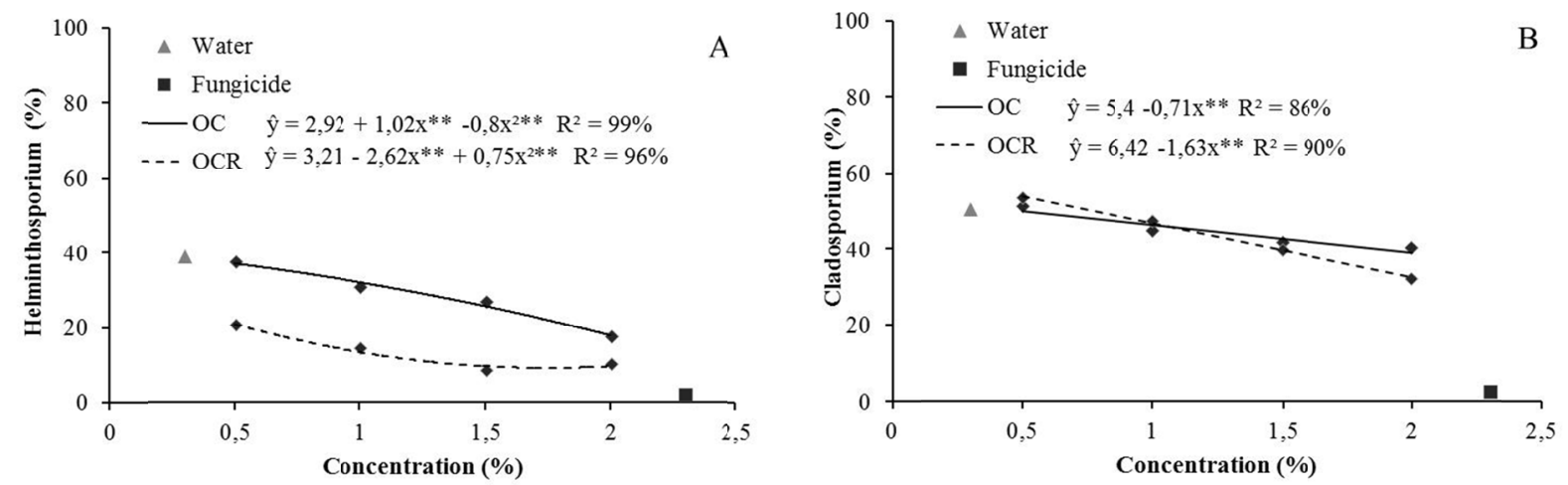

Figure 3. Incidence of Helminthosporium sp. (A) and Cladosporium sp. (B) in seeds of Calotropis procera treated with essential oils of Copaifera langsdorffii and Syzygium aromaticum from the municipality of Tacima, PB

Regarding the incidence of Clasdosporium, (Figure 3B) the oils tested were not as efficient in the control; a 50\% reduction of the control to $30 \%$ was verified when the seeds were treated with $2 \%$ clove oil. In this case, the essential oils probably have pathogen specificity. Thus, it is important to know the pathogens occurring in the seeds; the correct diagnosis will provide subsidies for later adoption of measures of fungus management in the seeds and increase of productivity (Vida et al., 2004). Seeds contaminated with Clasdosporium may result in low germination and vigor, especially in untreated seeds (Carvalho et al., 2011).

The concentration of clove oil at $2 \%$ differed significantly from the control (19\%), and did not differ from the fungicide (Captan $\left.{ }^{\circledR}\right)$ (Figure 4A), showing control of the incidence of Curvularia sp. The oils studied at the concentration of $0.5 \%$ did not differ from the control (19\%). Mondego et al. (2014), investigating methods of alternative microflora control in seeds of Pseudobombax marginatum with copaiba essential oil, for the incidence of Curvularia sp. observed that all doses of the oil differed significantly from the control (7\%) and did not differ from the fungicide (Captan $\left.{ }^{\circledR}\right)$. This fungus can be found frequently in different plant substrates such as saprophytic, phytopathogenic and endophytic, which can cause foliar stains in several plant families (Ferreira, 2010). 

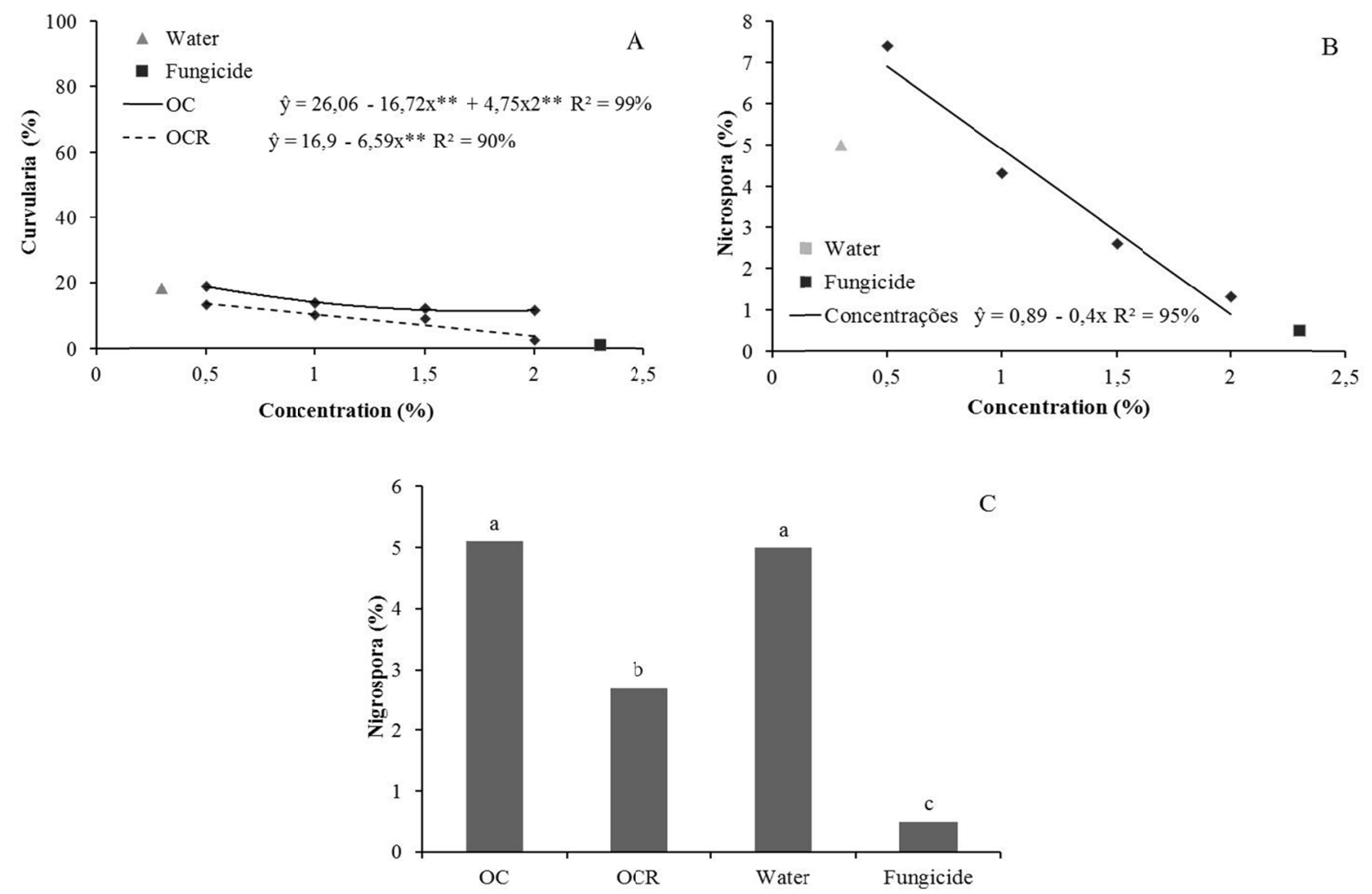

Figure 4. Incidence of Curvularia sp. (A) and Nigrospora sp. (B) in seeds of Calotropis procera treated with essential oils of Copaifera langsdorffii and Syzygium aromaticum from the municipality of Tacima, PB

Nigrospora sp. is a filamentous fungus widely distributed in soil, decaying plants and seeds. It is reported to be harmful to seed germination and seedling development (Sales, 1994). Even with low incidence on the seeds of $C$. procera is necessary its correct control. Clove essential oil showed a significant difference in relation to copaiba oil and water control, reducing the percentage of this fungus from $5 \%$ to $2.5 \%$ (Figure $4 \mathrm{C}$ ). Among the concentrations used, $2 \%$ showed the best control, differing statistically from the other concentrations and not differing from the fungicide, resulting in almost complete elimination of the pathogen. Several authors have reported the use of essential oils in the control of this fungus. Mata et al. (2009) observed that the growth of Nigrospora sp., Cladosporium sp., Curvularia sp. is controlled with the essential oil of fennel (Pimpinella anisum) in all concentrations used, but the essential oil of citronella (Cymbopogon winterianus) only controls Nigrospora sp. and Cladosporium sp. these results show that there are specific alternative controls for various genus of fungi.

In the evaluation of the physiological quality of the seeds, there was a decrease of $15 \%$ in the percentage of seed germination as a function of the concentration of essential oils (Figure 5A). The negative influence observed can be attributed to the fact that essential oils have substances such as Eugenol, a phenyl propene (phenol). Eugenol is little soluble in water, which is present in the essential oil of Syzygium aromaticum, which binds strongly to the tannin by means of hydrogen bonds and consequently, inhibits seed germination (Oliveira et al., 2011; Boukaew et al., 2017). 

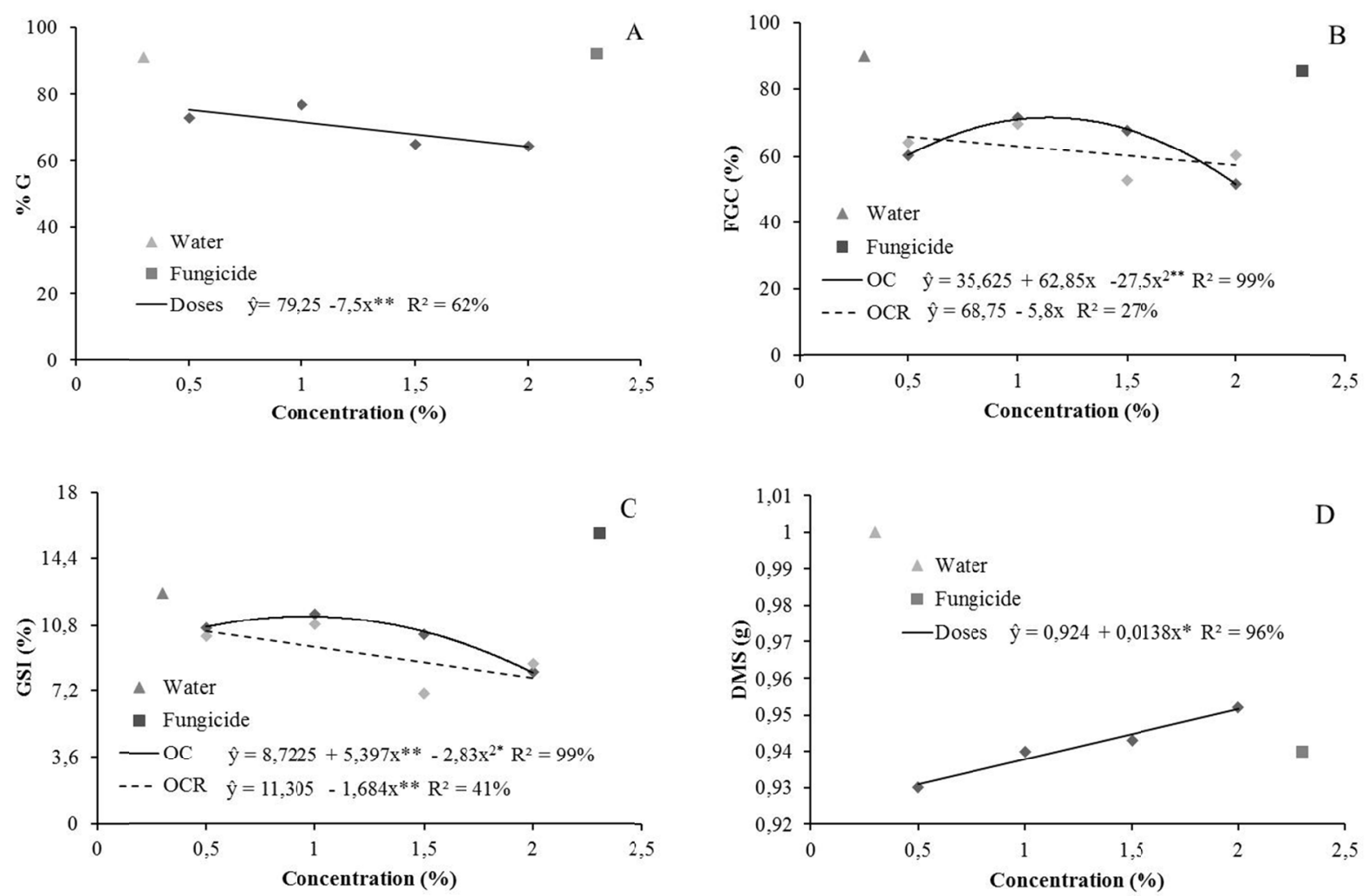

Figure 5. Germination (G); First Germination Count (FGC); Germination Speed Index (GSI); Dry mass of seedlings (DMS) in seeds of Calotropis procera submitted to treatment with Copaifera langsdorffii and Syzygium aromaticum oil

Other compounds are also responsible for inhibiting germination in different species such as Monotherpenes and oxygenated monoterpenes present in the oil of Piper hispidinervium C. DC. and sesquiterpenes, aliphatic and arylpropanoids found in the oil of Pogostemon heyneanus Benth (Souza Filho et al., 2009). In addition to the composition, the concentration of essential oils may influence the effect caused on germination as verified by Corlett et al. (2015), where concentrations of Cymbopogon winterianus oil above $0.05 \mathrm{~mL}$ caused inhibition of germination, with significant presence of abnormal and dead seedlings.

The first germination count (FGC) obtained maximum values of $69 \%$ and $66 \%$ in the concentration of $1.14 \%$ of essential oil of Copaifera langsdorffii and $0.5 \%$ of Syzygium aromaticum, respectively (Figure 5B), these doses favor the process germination because higher results at the first count result in higher percentages of normal seedlings. FGC is an important test of vigor, based on the principle that, samples with higher percentages of normal seedlings in the first count are the most vigorous, therefore, indispensable in evaluating the physiological quality of seeds (Nakagawa, 2012).

The germination speed index (GSI) presented a higher percentage $(11.30 \%)$ in the concentration of $0.95 \%$ of the essential oil of Copaifera langsdorffii, the percentage values related to the essential oil concentrations of Syzygium aromaticum showed a negative linear behavior as concentrations increased, decreasing from $10.46 \%$ to $7.93 \%$ (Figure 5C). In general, the IVG values were influenced by the application of the essential oils, possibly due to the allopathic effects caused by the application of the essential oils in the seeds of Calotropis procera. This inhibits the emission of the radicles since they hinder the cell division process, besides other functions such as enzyme activation and membrane permeability (Pinã-Rodrigues \& Lopes, 2001). This behavior may vary according to the species used, since in a research carried out by Mondego et al. (2014) using Copaifera langsdorffii essential oil as an alternative control of Pseudobombax marginatum seed microflora observed that the treatments did not affect germination or seed vigor.

For the dry matter of seedling (MS) there was a growth as a function of the concentrations of essential oils from $0.93 \mathrm{~g}$ to $0.95 \mathrm{~g}$ (Figure 5D). These results differ from those reported by Farias et al. (2016) when testing the three concentrations of oils ( $0,0.5 \%, 1.0 \%$ and 2\%) of Andiroba (Carapa guianensis Aubl.) And Copaíba (Copaifera langsdorffi Desf) on the health and physiology of seeds of two varieties (Vigna unguiculata L. Walp), 
BRS Gurgueira and Marataoã, in both varieties no differences were observed when comparing the control in the treatment with Copaiba oil, with a slight increase of the dry mass in the concentration of $2 \%$ of the oil of Andiroba. However, Mondego et al. (2016) recorded higher mean MS using Copaifera langsdorffii essential oil in this way proving beneficial effects and viability in their use.

\section{Conclusions}

The essential oils of Clove (Syzygium aromaticum) and Copaíba (Copaifera langsdorffii) considerably reduced the incidence of pathogens in silk flower seeds (Calotropis procera);

The concentration of $2.0 \%$ of the oil of $S$. aromaticum provided a reduction in the percentage of the fungal microflora of the genus Altenaria sp. and Curvularia sp., not differing from the fungicide;

The increasing concentrations of the oils $S$. aromaticum and $C$. langsdorffii present a phytotoxic effect, moderately reducing the germination and vigor of $C$. procera seeds.

\section{References}

Amaral, M. F. Z. J., \& Bara, M. T. F. (2005). Avaliação da atividade antifúngica de extratos de plantas sobre o crescimento de fitopatógenos. Revista Eletrônica de Farmácia, 2(2), 5-8.

Boukaew, S., Prasertsan, P., \& Sattaysamitsathit, S. (2017). Evaluation of antifungal activity of essential oils against aflatoxigenic Aspergillus flavus and their allelopathic activity from fumigation to protect maize seeds during storage. Industrial Crops and Products, 97(97), 558-566. https://doi.org/10.1016/j.indcrop. 2017.01.005

Carvalho, D. D. C., Mello, S. C. M., Júnior, M. L., \& Geraldine, A. M. (2011). Biocontrol of seed pathogens and growth promotion of common bean seedlings by Trichoderma harzianum. Pesquisa Agropecuária Brasileira, 46(6), 822-828. https://doi.org/10.1590/S0100-204X2011000800006

Carvalho, N. M., \& Nakagawa, J. (2012). Sementes: Ciência, tecnologia e produção (5th ed., p. 590). FUNEP.

Costa, A. R. T., Amaral, M. F. Z. J., Martins, P. M., Paula, J. A. M., Fiuza, T. S., Tresvenzol, L. M. F., ... Bara, M. T. F. (2011). Ação do óleo essencial de Syzygium aromaticum (L.) Merr. \& L. M. Perry sobre as hifas de alguns fungos fitopatogênicos. Revista Brasileira de Plantas Medicinais, 13(2) 240-245. https://doi.org/ $10.1590 / \mathrm{S} 1516-05722011000200018$

Daferera, D. J., Ziogas, B. N., \& Polissiou, M. G. (2003). The effectiveness of plant essential oils on the growth of Botrytis cinerea, Fusarium sp., and Clavibacter michiganensis subsp. michiganensis. Journal of Crop Protetion, 22, 39-44. https://doi.org/10.1016/S0261-2194(02)00095-9

Farias, O. T., Nascimento, L. C., Oliveira, F. S., Santos, M. D. R., \& Bruno, R. L. A. (2016). Óleo essencial de Andiroba (Carapa guianensis Aubl.) e copaíba (Copaifera langsdorffi Desf) sobre a sanidade e fisiologia de sementes de feijão Macassar (Vigna unguiculata L. Walp). Revista Brasileira Plantas Medicinais, 18(3), 629-635.

Ferreira, D. F. (2014). Sisvar: A guide for its bootstrap procedures in multiple comparisons. Ciência e Agrotecnolgia, 38(2), 109-112. https://doi.org/10.1590/S1413-70542014000200001

Ferreira, L. S. (2010). Caracterização de isolodos de Curvularia sp. endofiticos de milho (Zea mays L.) por parâmetros morfológicos e moleculares. Paraná, Brazil.

Gayoso, C. W., Lima, E. O., Oliveira, V. T., Pereira, F. O., Souza, E. L., \& Lima, I. O. (2005). Sensitivity of fungi isolated from onychomycosis to Eugenia cariophyllata essential oil and eugenol. Fitoterapia, 76(2), 247-9. https://doi.org/10.1016/j.fitote.2004.12.005

Gomes, R. S. S., Nunes, M. C., Nascimento, L. C., Souza, J. O., \& Porcino, M. M. (2016). Eficiência de óleos essenciais na qualidade sanitária e fisiológica em sementes de feijão-fava (Phaseolus lunatus L.). Revista Brasileira de Plantas Medicinais, 18(1) 279-287. https://doi.org/10.1590/1983-084X/15_117

Goulart, A. C. P. (2001). Incidência e controle químico de fungos em sementes de soja em alguns municípios de Mato Grosso do Sul. Ciência e Agrotecnologia, 25(6), 1457-1466.

Lazarotto, M., Girardi, L. B., Mezzomo, R., Piveta, G., Muniz, M. F. B., \& Blume, E. (2009). Tratamentos Alternativos para o Controle de Patógenos em Sementes de Cedro (Cedrela fissilis) (pp. 75-77). VI Congresso Brasileiro de Agroecologia e II Congresso Latinoamericano de Agroecologia.

Maguire, J. D. (1962). Seed of germination, aid in selection and evaluation for seedling emergence and vigor. Crop Science, 2(1), 176-177. https://doi.org/10.2135/cropsci1962.0011183X000200020033x 
MAPA (Ministério da Agricultura, Pecuária e Abastecimento). (2009). Regras para análise de sementes (p. 399). Brasília: MAPA/ACS.

Mariod, A. A., Mirghani, M. E. S., \& Hussein, I. (2017). The potential of Apple (Calotropis procera and Calotropis gigantea) Sees Oil. Unconvertional Oilseeds and Oil Sources (pp. 382-383). Libgen Librarian.

Mata, M. F., Araujo, E., Nascimento, L. C., Souza, A. E. F., \& Viana, S. (2009). Incidência e controle alternativo de patógenos em sementes de mandacaru (Cereus jamacaru DC, Cactaceae). Revista Brasileira Biociência, 7(4), 327-334.

Mondego, J. M., Melo, P. A. F. R., Kedma, M. S. P., Nascimento, L. C., Alves, E. E., \& Batista, J. L. (2014). Controle alternativo da microflora de sementes de Pseudobombax marginatum com oléo essêncial de copaíba (Copaifera sp.). Bioscience Journal, 30(2) 349-355.

Nakagawa, J. (1999). Testes de vigor baseados na avaliação de plântulas. In F. C. Krzyzanowski, R. D. Vieira, J. B. França Neto (Eds.), Vigor de sementes: Conceitos e testes (Cap. 2). Abrates.

Oliveira, J. A., Silva, T. T. D. A., Pinho, E. V. D. V., \& Abreu, L. A. S. (2011). Secagem e armazenamento de sementes de sorgo com alto e baixo teor de tanino. Revista Brasileira de Sementes, 33(4), 699-710. https://doi.org/10.1590/S0101-31222011000400012

Oliveira-Bento, S. R. S., Torres, S. B., Oliveira, F. N., Paiva, E. P., \& Bento, D. A. V. (2013). Biometria de frutos e sementes e germinação de Calotropis procera Aiton W.T. Aiton (Apocynaceae). Bioscience Journal, 29(5), 1194-1205.

Pereira, C. E., Oliveira, J. A., Rosa, M. C. M., Oliveira, G. E., \& Neto, J. C. (2009). Tratamento fungicida de sementes de soja inoculadas com Colletotrichum truncatum. Ciência Rural, 39(9), 2390-2395. https://doi.org/10.1590/S0103-84782009005000215

Piña-Rodrigues, F. C. M., \& Lopes, B. M. (2001). Potencial alelopático de Mimosa caesalpinaefolia Benth sobre sementes de Tabebuia alba (cham.) Sandw. Floresta e Ambiente, 8(1), 130-136.

Ranasinghe, L., Jayawardena, B., \& Abeywickrama, K. (2012). Fungicidal activity of essential oil of Cinnamomum zeylanicum (L.) and Syzygium aromaticum (L.) L. M. Perry against crown rot and anthracnose pathogens isolated from banana. Letters in Applied Microbiology, 35(3), $208-11$. https://doi.org/10.1046/j.1472-765X.2002.01165.x

Rangel, E. S., \& Nascimento, M. T. (20110. Ocorrência de Calotropis procera (Ait.) R. Br. (Apocynaceae) como espécie invasora de restinga. Acta Botânica Brasílica, 25(3), 657-663. https://doi.org/10.1590/S0102-330 62011000300019

Sales, N. L. P. (1994). Efeito da população fúngica sobre a germinação das sementes e do desenvolvimento de ipê-amarelo (Tabebuia serrratifolia) e barbatimão (Stryphnodendron adstringens). Ciência e Prática, 18(1), 83-9.

Santana, A. P. S. (2015). Efeitos de produtos alternativos no controle de doenças na videira (118f, Tese, Faculdade de Engenharia, Universidade Estadual Paulista Júlio de Mesquita Filho, São Paulo).

Santos, E. S., Carvalho, R. A., \& Lacerda, J. T. (2008). Alternativas naturais e ecológicas no controle de doenças fúngicas do inhame (Dioscorea spp.). Tecnologia \& Ciência Agropecuária, 2(2), 1-6.

Sartorelli, P., Marquioreto, A. D., Amaral-Baroli, A., Lima, M. E., \& Moreno, P. R. (2007). Chemical Composition and Antimicrobial Activity of the Essential Oils from Two Species of Eucalyptus. Phytotherapy Research, 3(21), 231-3. https://doi.org/10.1002/ptr.2051

Souza filho, A. P. S., Vasconcelos, M. A. M., Zoghbi, M. G. B., \& Cunha, R. L. (2009). Efeitos potencialmente alelopáticos dos óleos essenciais de Piper hispidinervium C. DC. e Pogostemon heyneanus Benth sobre plantas daninhas. Acta Amazonica, 39(2), 389-395.

Torres, J. F., Braga, A. P., Costa Lima, G. F., Rangel, A. H. N., Lima Júnior, D. M., \& Maciel, M. V. (2010). Utilização do feno de flor-de-seda (Calotropis procera Ait. R. Br) na alimentação de ovinos. Acta Veterinária Brasileira, 4(1), 42-50.

Vida, J. B., Zambolim, L., Tessmann, D. J., Brandão filho, U. T., Verzignassi, J. R., \& Caixeta, M. P. (2004). Manejo de doenças de plantas em cultivo protegido. Fitopatologia Brasileira, 29, 355-372. https://doi.org/ 10.1590/S0100-41582004000400001 
Zimmermam-Franco, D. C., Bolutari, E. B., Polonini, H. C., Carmo, A. M., Chaves, M. D., \& Raposo, N. R. (2013). Antifungal Activity of Copaifera langsdorffii Desf Oleoresin against Dermatophytes. Molecules, 18(10), 12561-12570. https://doi.org/10.3390/molecules 181012561

\section{Copyrights}

Copyright for this article is retained by the author(s), with first publication rights granted to the journal.

This is an open-access article distributed under the terms and conditions of the Creative Commons Attribution license (http://creativecommons.org/licenses/by/4.0/). 